\begin{tabular}{|l|l|l||}
\hline \multicolumn{2}{|c|}{ PublisherInfo } \\
\hline \hline PublisherName & $:$ & BioMed Central \\
\hline \hline PublisherLocation & $:$ & London \\
\hline \hline PublisherImprintName & $:$ & BioMed Central \\
\hline \hline
\end{tabular}

\title{
Dissecting dyskerin
}

\begin{tabular}{|l|l|l||}
\hline \multicolumn{2}{|c|}{ ArticleInfo } \\
\hline \hline ArticleID & $:$ & 4678 \\
\hline \hline ArticleDOI & $:$ & $10.1186 /$ gb-spotlight-20030115-01 \\
\hline \hline ArticleCitationID & $:$ & spotlight-20030115-01 \\
\hline \hline ArticleSequenceNumber & $:$ & 30 \\
\hline \hline ArticleCategory & $:$ & Research news \\
\hline ArticleFirstPage & $:$ & 1 \\
\hline \hline ArticleLastPage & $:$ & 2 \\
\hline \hline & & RegistrationDate : 2003-1-15 \\
\hline ArticleHistory & $:$ & OnlineDate \\
\hline \hline ArticleCopyright & $:$ & BioMed Central Ltd2003-15 \\
\hline \hline ArticleGrants & $:$ & \\
\hline \hline ArticleContext & $:$ & 130594411 \\
\hline \hline
\end{tabular}




\section{Jonathan B Weitzman}

Email: jonathanweitzman@hotmail.com

The DKC1 gene encodes dyskerin, a pseudouridine synthase that binds to box $\mathrm{H}+\mathrm{ACA}$ small nucleolar RNAs and to the RNA component of telomerase. $D K C 1$ mutations cause dyskeratosis congenital, a rare recessive disease characterized by premature aging and cancer susceptibility. In the January 10 Science, Ruggero et al. describe analysis of a hypomorphic $D k c l$ mutant mouse that manifests features of the human disease (Science 2003, 299:259-262). The mice have a two- to four-fold reduction in $D k c l$ expression. By six months of age, over half the mice developed dyskeratosis syndrome symptoms, such as severe anemia, lymphopenia, dyskeratosis of the skin, and bone marrow failure. The animals were also highly prone to tumors, especially of the lung and mammary gland. After four generations, mutant mice began to show loss of telomeric repeats and of telomerase activity. The $D k c l$ hypomorph provides a useful model of the human disease and demonstrates the importance of its role in rRNA modification.

\section{References}

1. X-linked dyskeratosis congenita is caused by mutations in a highly conserved gene with putative nucleolar functions.

2. Dyskeratosis congenita, X-linked, [http://www.ncbi.nlm.nih.gov/entrez/dispomim.cgi?id=305000]

3. Science, [http://www.sciencemag.org] 